\title{
THE DEVELOPMENT OF AN ASSESSMENT INSTRUMENT OF TECHNOLOGICAL PEDAGOGICAL CONTENT KNOWLEDGE (TPACK) FOR PRIMARY SCIENCE TEACHERS IN MALAYSIA
}

\author{
${ }^{1}$ Mohammed Yousef Mai, ${ }^{2}$ Mahizer Hamzah \\ ${ }^{1,2}$ Faculty of Human Development \\ Universiti Pendidikan Sultan Idris
}

\begin{abstract}
The TPACK framework represents the knowledge needed by teachers bringing together content knowledge, technological knowledge and pedagogical knowledge with the aim of integrating ICTs into teachinglearning processes. The aim of this study is to addresses the need for a survey instrument designed to assess TPACK for primary science teachers in Malaysia. The paper describes survey development process and results from 220 primary science teachers in Malaysia $($ Female=106, Male=104). Data were collected through "Technological Pedagogical and Content Knowledge" (TPACK) scale. The questionnaire consisted of 47 questions within 7 factors about TPACK and is based on the survey instrument developed by Schmidt et al., (2009). Data analysis procedures included Cronbach's alpha statistics on the TPACK knowledge domains and factor analysis for each domain. Results suggest that, with the modification and/or deletion of 5 of the survey items, the survey is a reliable and valid instrument that will help researchers to assess primary science teachers' perceptions of TPACK. In future research, other variables might be included to analyze their impact on preservice science teachers' TPACK.
\end{abstract}

Keywords TPACK, Factor Analysis, Primary science teacher.

\begin{abstract}
Abstrak
Rangka kerja TPACK mewakili pengetahuan yang diperlukan oleh guruguru membawa bersama pengetahuan kandungan, pengetahuan teknologi dan pengetahuan pedagogi dengan tujuan untuk mengintegrasikan ICT dalam proses pengajaran-pembelajaran. Tujuan kajian ini adalah menangani keperluan kajian instrumen yang direka bagi menilai TPACK untuk guruguru sains sekolah rendah di Malaysia. Kertas kerja ini menerangkan proses kajian pembangunan dan hasil dari 220 guru sains sekolah rendah di Malaysia $($ Perempuan $=106$, Lelaki $=104)$. Data dikumpulkan melalui "Teknologi Pedagogi dan skala Kandungan Pengetahuan" (TPACK). soal selidik ini terdiri daripada 47 soalan melibatkan 7 faktor tentang TPACK dan adalah berdasarkan kepada instrumen kajian yang dibangunkan oleh Schmidt et al., (2009). Prosedur-prosedur analisis data termasuk statistik alpha Cronbach's domain pengetahuan TPACK dan faktor analisis untuk setiap domain. Keputusan menunjukkan bahawa, dengan pengubahsuaian dan atau penghapusan 5 item kaji selidik, kaji selidik itu adalah instrumen
\end{abstract}


yang boleh dipercayai dan sah yang akan membantu penyelidik untuk menilai persepsiguru-guru sains sekolah rendah mengenai TPACK. Dalam kajian masa depan, pembolehubah lain yang perlu dimasukkan untuk menganalisis kesannya terhadap perkhidmatan TPACK guru sains

Kata kunci $\quad$ TPACK, Faktor Analisis, Guru Sains Sekolah Rendah.

\section{INTRODUCTION}

The Malaysian Ministry of Education (MOE) has introduced various initiatives to facilitate the adoption and diffusion of Information and Communication Technology (ICT). In line with the Vision 2020, Ministry of Education has draft ways to integrate ICT into the education system. The Malaysian government has invested millions of Ringgit for the usage of ICT in education (Rashid, 2011). The Ministry has formulated three main policies for ICT in education (Chan, By, 2002; Mohd Zaki M., Faizal M.A., Erman H., Nazrulazhar B., A., Nor Azman M., \& Y., 2009):

1. ICT is for all students, meaning that ICT is used as an enabler to reduce the digital gap between the schools.

2. Emphasizes the role and function of ICT in education as a teaching and learning tool, as part of a subject as well as a subject by itself.

3. Emphasizes the use of ICT to increase productivity, efficiency and effectiveness of the management system such as the processing of official forms, timetable generation, management of information systems, lesson planning, financial management and the maintenance of inventories.

Much discussion about technology and education has focused on the question of how technology facilitates teaching and learning. Look (2005) cited that a review of 219 studies on the use of technology in education consistently found that students in technology rich environments experienced positive effects on achievement in all subject areas. The merits of ICT in education have been extolled in the literature. The use of ICT has been found to (Fu, 2013; Kubiatko, M. , \& Haláková, 2009; Look, 2005; Sim, Janice CH, \& Theng, 2014):

1. Assist students in accessing digital information efficiently and effectively.

2. Support student-centered and self-directed learning.

3. Produce a creative learning environment.

4. Promote collaborative learning in a distance-learning environment.

5. Offer more opportunities to develop critical (higher-order) thinking skills.

6. Support teaching by facilitating access to course content.

7. ICT offers students more time to explore beyond the knowledge allowing them to understand better the scientific concepts.

8. ICT enhances the effectiveness of information presentation and stimulates students' interest.

9. ICT can improve the quality of education. 
10. The use of multimedia approach had been successful in generating conceptual understanding.

11. The use of interactive multimedia software motivates students and leads to improved performance.

12. Using ICT increase the students' attitudes.

The use of ICT has greatly transformed the outcomes of teaching and learning experience in classrooms. It does not only supplement and/or complement teacher instructional processes, but also offers unlimited access to knowledge and information that is readily available through the internet, manipulate data, explore relationships, intentionally and actively process information, construct personal and socially shared meaning and reflect on the learning process. It also gives the students opportunities to examine a variety of viewpoints so they can construct their own knowledge of various concepts (Koç, 2005; Tam, 2000).

Further, research studies showed that ICT motivate student learning, there are a lot of assumptions that students are interested in using ICT; they found it more pleasant, more appealing, and more motivating to study with ICT tools than by traditional means (Kubiatko \& Haláková, 2009). Multimedia and technology have proven helpful in engaging students in learning about subjects, in exploring ways to present their learning, and in helping students control their learning (Taylor, L. , \& Parsons, 2011). In sum, although the use of ICT changes the teaching and learning relationship, but there is a lack of theoretical grounding for developing or understanding this process of integration ICT in the teaching and learning (Mishra \& Koehler, 2006)while addressing the complex, multifaceted, and situated nature of this knowledge. We argue, briefly, that thoughtful pedagogical uses of technology require the development of a complex, situated form of knowledge that we call Technological Pedagogical Content Knowledge (TPCK).

\section{THEORETICAL BACKGROUND}

For several decades, educational technology as a field has struggled to find its theoretical roots (Graham, 2011), developing theory for educational technology is difficult because it requires a detailed understanding of complex relationships that are contex- tually bound. Moreover, it is difficult to study cause and effect when teachers, classrooms, politics, and curriculum goals vary from case to case (Mishra \& Koehler, 2006). Acoording to Khaddage \& Knezek (2013), educational technology researchers around the world who are interested in issues related to technology integration (Khaddage, Ferial, \& Knezek, 2013), therefore, they are increasing the use of the technological pedagogical content knowledge (TPACK) framework in the recent studies (Graham, 2011). The most important influence of technological pedagogical content knowledge (TPACK) framework is for thinking about teacher knowledge (what they need to know, and how they might develop it) and the importance of pedagogical approach to teachers' professional development, learning technology by design, leads to the development of TPACK (Mishra \& Koehler, 2006). 
Teaching is a complex cognitive skill occurring in an ill-structured, dynamic environment. It is important to understand that teaching is a highly complex activity that draws on many kinds of knowledge. Historically, teacher education have focused on the content knowledge of the teacher. More recently, teacher education has shifted its focus to general pedagogical classroom practices independent of subject matter and often at the expense of content knowledge. This lead teacher education to emphasize one or the other domain of knowledge, focusing on knowledge of content (C) or knowledge of pedagogy (P) (Mishra $\&$ Koehler, 2006). The TPACK framework builds on Shulman's (1986, 1987) conception of pedagogical content knowledge (PCK) by explicitly integrating the component of technological knowledge into the model (Graham, 2011). The TPACK framework is most commonly represented using a Venn diagram with three overlapping circles, each representing a distinct form of teacher knowledge (see Figure 1).

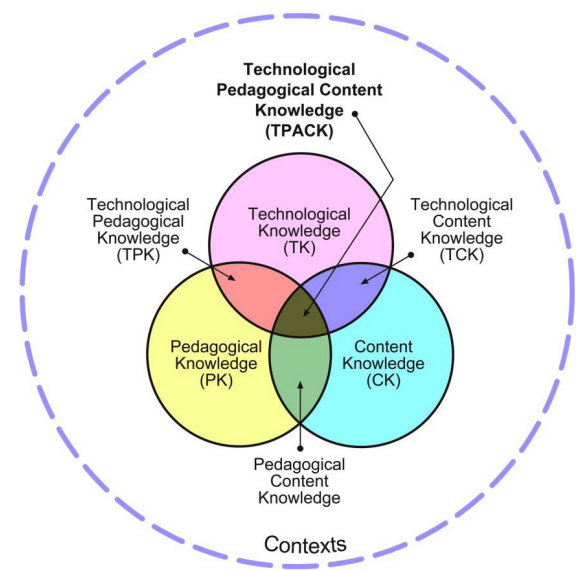

TPACK framework (Mishra \& Koehler, 2006)

The TPACK framework highlights three core knowledge components: Content, Pedagogy, and Technology. It refers to the knowledge that emerges from an understanding of an interaction of these three components (Karadeniz \& Vatanartıran, 2013 and Chai \& Tsait 2010). Therefor, TPACK framework includes three core categories of knowledge: pedagogical knowledge (PK), content knowledge $(\mathrm{CK})$, and technological knowledge (TK). The framework proposes that combining these three core types of knowledge results in four additional types of knowledge: pedagogical content knowledge (PCK), technological pedagogical knowledge (TPK), technological content knowledge (TCK), and technological pedagogical content knowledge (TPACK) (Graham, 2011; Koehler, Matthew J.; Mishra, Punya; Cain, 2013).

The different components of TPACK framework are described as follows: (Mishra \& Koehler, 2006; Doukakis, S., Psaltidou, A., Stavraki, A., Adamopoulus, N., Tsiotakis, P. \& Stergou, 2010; Graham, 2011; Harris \& Hofer, 2011; Karadeniz \& Vatanartiran, 2013; Koehler, Matthew J.; Mishra, Punya; Cain, 2013; RoigVila, Mengual-Abdres, \& Quinto-Medrano, 2015). 
1. Technological Knowledge (TK): Technological knowledge is the knowledge about the various technologies, ranging from low-tech technology such as pencil and paper to digital technology such as the internet, digital video, interactive whiteboard etc. It refers to the knowledge about all sorts of technology -not only computers.

2. Content Knowledge (CK): Content knowledge is about the knowledge that a teacher is having on Mathematics or Science subjects which he/she teaches, it covers the knowledge linked to a subject matter.

3. Pedagogical Knowledge (PK): This describes the knowledge of the teacher about the processes and practices of teaching and learning, it includes knowledge about classroom management and organisation; curricular analysis and planning; and student's learning.

4. Technological Pedagogical Knowledge (TPK): It entails understanding how various technologies tools can be used in teaching, along with the conviction that the use of technology can change the way in which teachers improve their pratices and develop their professional activity.

5. Technological Content Knowledge (TCK): This is the knowledge of how technology can create new representations and/or new learning scenarios for specific contents

6. Pedagogical Content Knowledge (PCK): Pedagogical content knowledge integrates both content and pedagogy with the goal of developing better teaching practices in the content area.

7. Technological Pedagogical Content Knowledge (TPACK): This refers to the knowledge required by teachers for integrating technology into their teaching and content area. Teachers have an intuitive knowledge of the complex interrelationships existing between the three basic component of knowledge (CK, PK, TK) which is reflected in their ability to teach using the appropriate pedagogical methods and technologies.

TPACK framework gives flexibility and provides dynamic strategies to teachers to enhance and therefore improve the teaching and learning process (Junnaina \& Hazri, 2014). According to Hasniza Nordin (2014) the use of the TPACK framework can create an added value since the structure of this particular model can be used to:

1. simplify topics that are not easy for teachers to understand.

2. help teachers to increase their competencies by being able to create good educational materials and useful instructional material designs that can utilize both pedagogical knowledge and ICT.

3. allow teachers to develop strategies that will be effective for students' learning.

4. enable teachers to effectively integrate the use of ICT in designing content.

5. increase teachers' skills not only in the use of effective technology when designing course-related content and pedagogy.

6. help teachers to design and implement useful content-based lectures using a wide-range of ICT (such as design tools in Web 2.0). 
7. enabled teachers to shift their focus from the use of social networking tools to re-designing the main uses of the social networking tools.

The studies about TPACK are varied in their aims, a range of research has identified the usefulness of the TPACK framework to inform the provision of teacher education (Hasniza Nordin, 2014) while some other studies aimed at adapting technological pedagogical and content knowledge (TPACK) instrument. For instance, Karadeniz and Vatanartiran ( 2013) administered a survey to 285 teachers who teach a variety of subject areas at the secondary school level in Edirne, Turky. The CFA results showed that original 5 factor scale fitted with Turkish data and TPACK survey was a valid and reliable instrument for measuring secondary school teachers' TPACK.

\section{PURPOSE OF THE STUDY}

In recent years, a new model for teachers' technology integration has been developed. This model requires teachers' competency in technology pedagogy and content to form the technological pedagogical content knowledge (TPACK). TPACK is a specialized, highly applied type of knowledge that supports contentbased technology integration. It has been characterized as the multiple intersections of teachers' knowledge of curriculum content, general pedagogies, technologies, and contextual influences upon learning (Harris \& Hofer, 2011). Most important, the TPACK framework allows us to identify what is important and what is not in any discussions of teacher knowledge surrounding using technology for teaching subject matter (Mishra \& Koehler, 2006).

Building on a history of using survey methods to assess teachers' levels of technology integration, researchers have started work on creating survey instru $\neg$ ments that assess teachers' perceptions of TPACK. These surveys emphasize teachers' self-assessed levels of knowledge in each of the TPACK domains.

In particular, the purpose of this study was to develop and validate an instrument designed to measure preservice teachers' self-assessment of their Technological Pedagogical Content Knowledge (TPACK) and related knowledge domains included in the framework.

\section{METHODOLOGY}

\section{Research Design}

This research aimed at developing and validating the Survey of science teachers' Knowledge of Teaching and Technology to collect data on science teachers' selfassessment of the seven knowledge domains within the TPACK framework. The researcher specifically designed the instrument for primary science teachers. This research is a descriptive in nature; its key purpose is a description of the state of affairs, as it exists at present. Surveys are concerned with describing, recording, analyzing and interpreting conditions that exist (Kothari, 2004). In this study, qualitative data were obtained through a survey conducted with science teachers 
in primary school, the gathered data were analyzed using both descriptive and inferential statistics.

\section{Participants}

The research sample consist of 210 science teachers who teaching science in primery schools in Selangor and Perak in Malaysia in the academic year of 2015-2016. The male teachers $(n=104)$ form $49.5 \%$ of the sample while the female teachers $(n=106)$ form $50.5 \%$ of the sample. Approximately $21.4 \%$ of the respondents aged (25-30 years old), 45.7\% aged $31-35$ years, and $32.9 \%$ aged more than 35 years old.

\section{Developing the Instrument}

Several studies have acknowledged the need to develop a more reliable and valid instrument when measuring teachers' TPACK (Hasniza Nordin, 2014)in both developed and developing countries. A number of initiatives have been made in the development of ICT related training in Initial Teacher Education (ITE. The first step in developing the TPACK survey involved reviewing relevant literature that cited numerous instruments that were already being used for assessing technology use in educational settings.

In this research, data were collected through "Technological, Pedagogical, and Content Knowledge" scale. It consists of 47 items about TPACK on a 5-point Likert scale and is based on the survey instrument developed by Schmidt et al. (2009). TPACK model 47 items in the questionnaire are divided into questions about TK (15 items), PK (6 items), CK (6 items), TPK (4 items), PCK (7 items), TCK (4 items) and TPACK (5 items). Every item in the questionnaire is 5 Likert scale. Likert scale question comprised five points ranking following: "strongly agree" (5 points), "agree" (4 points), "neutral" (3 points), "disagree" (2 points), "strongly disagree" (1 point). For each subscale (CK, TK,PK, PCK, TCK, TPK, TPACK) the participant's responses are averaged. In addition, the questionnaire utilised covers also with the same demographic data (gender and age). Cronbach's alpha, the measure of reliability, was calculated for the scales and subscales for items measured on the five-point Likert scale.

\section{Data Analysis}

Factor analysis is a collection of methods used to examine how underlying constructs influence the responses on a number of measured variables, there are basically two types of factor analysis: exploratory and confirmatory:

- Exploratory factor analysis (EFA) attempts to discover the nature of the constructs influencing a set of responses.

- Confirmatory factor analysis (CFA) tests whether a specified set of constructs is influencing re- sponses

In the process of developing TPACK instrument, the researcher assessed each TPACK knowledge domain subscale for internal consistency using Cronbach's alpha reliability technique. In addition, the researcher used EFA to discover the number of factors influencing variables and to analyze which variables 'go 
together' (DeCoster, 1998). The researcher investigated construct validity for each knowledge domain subscale using principal components factor analysis with varimax rotation within each knowledge domain and Kaiser normalization (Schmidt et al., 2009). Factors that have less than three variables, many complex variables and item loadings that are less than .32 are generally viewed as undesirable (Yong \& Pearce, 2013). Furthermore, item-total correlations and Cronbach's alpha internal consistency coefficient are calculated.

\section{RESEARCH RESULTS}

Factor analysis involves a series of analyses used to develop a rigorous instrument. For this analysis, the first step involved running a factor analysis on the items within each subscale to ascertain the covariation among the items and whether the patterns fit well into the TPACK constructs. The researchers used the KaiserGuttman rule (which states that factors with Eigen values greater than 1 should be accepted) to identify a number of factors and their constitution based on the data analysis (Schmidt et al., 2009).

As mentioned above, the survey used in this research consists of seven subscales forming the TPACK model: 1) TK, 2) PK, 3) CK, 4) TPK, 5) TCK, 6) PCK, and 7) TPACK. This research study is conducted in two phases; testing the reliability, and the validity. In the first step, the researcher examined questionable items for each TPACK domain subscale and eliminated those items that either reduced the reliability coefficient for the subscales or effects the construct validity (especially the items with loadings factor less than .32). Thus, the researcher dropped five items from TK subscale because it effects the construct validity of this subscale and because they has loading factors less than .32 (Yong \& Pearce, 2013).

Cronbach's alpha, the measure of reliability, was calculated for the scales and subscales for items measured on the five-point Likert scale. The overall scale had an alpha of 0.948 and the alpha for subscales ranged from 0.822 to 0.888 . The instrument has a good reliability and can be used to measure the science teachers' perceptions towards TPACK. For more detailes, the internal consistency scores for each subscale calculated are determined as 0.888 for TK, 0.863 for PK, 0.84 for CK, 0.88 for TPK, 0.822 for TCK, 0.883 for PCK, and 0.876 for TPACK.

The second step involves testing the construct validity of the TPACK survey. The factor validity of the seven subscales is examined using exploratory factor analysis (EFA). EFA is used to verify whether the survey items for each subscale successfully measure each variable. The Kaiser-Meyer-Olkin (KMO) measure of sampling adequacy and Bartlett's Test of Sphericity (BTS) are applied to the data prior to factor extraction to ensure the characteristics of the data set are suitable for EFA. Since the KMO and BTS results indicate the data satisfy the psychometric criteria for factor analysis, the EFA is performed.

Before conducting factor extraction, the KMO and BTS are applied to ensure that characteristics of the data set are suitable for factor analysis. Factor loadings along with the KMO and BTS results are provided in Table 1. 
Table 1 Factor Loadings for Each Subscale

\begin{tabular}{|c|l|l|l|l|l|l|l|}
\hline Item & TK & PK & CK & TPK & TCK & PCK & TPACK \\
\hline 1 & .372 & .568 & .499 & .660 & .603 & .726 & .433 \\
\hline 2 & .528 & .600 & .451 & .755 & .566 & .618 & .618 \\
\hline 3 & .434 & .714 & .416 & .658 & .662 & .720 & .699 \\
\hline 4 & .730 & .675 & .768 & .590 & .659 & .872 & .489 \\
\hline 5 & .494 & .641 & .652 & & .673 & & .782 \\
\hline 6 & .427 & .400 & .580 & & .559 & & \\
\hline 7 & .521 & & & & .449 & & \\
\hline 8 & .427 & & & & & & \\
\hline 9 & .631 & & & & & & \\
\hline 10 & .565 & & & & & & \\
\hline
\end{tabular}

Table 2 Factor Loadings for Each Subscale

\begin{tabular}{|c|c|c|c|c|c|c|c|}
\hline KMO & .769 & .840 & .796 & .751 & .818 & .787 & .752 \\
\hline BTS & 1283.086 & 562.062 & 562.885 & 311.786 & 775.004 & 479.368 & 436.547 \\
\hline df & 45 & 15 & 15 & 6 & 21 & 6 & 10 \\
\hline $\mathrm{p}$ & 0.001 & 0.001 & 0.001 & 0.001 & 0.001 & 0.001 & 0.001 \\
\hline
\end{tabular}

Overall, KMO analysis yields higher indexes with statistically significant BTS scores. The KMO and BTS results indicate the data satisfy the psychometric criteria for performing a factor analysis. As seen in Table 1, the factor loads related to the 42 items on the subscales range from 0.37 to 0.782 . From this point, it is determined these items are qualified sufficiently to be included in the scale.

Table 3 Eigen Value and Percentage of Variance for Each Factor

\begin{tabular}{|c|c|c|}
\hline Factor & Eigen Value & Percentage of Variance (\%) \\
\hline TK & 5.130 & 51.296 \\
\hline PK & 3.598 & 59.969 \\
\hline CK & 3.366 & 56.108 \\
\hline TPK & 2.663 & 66.584 \\
\hline TCK & 4.171 & 59.584 \\
\hline PCK & 2.937 & 73.418 \\
\hline TPACK & 3.021 & 60.419 \\
\hline
\end{tabular}

In addition, the correlations among the factors are given in Table 4. Statistically significant correlations exist among the subscales of the TPACK survey. These results show knowledge in technology, pedagogy, content, and their intersections are related. 
Table 4 Pearson Correlation Coefficients between Subscales

\begin{tabular}{|c|c|c|c|c|c|c|c|}
\hline & TK & PK & CK & TPK & PCK & TCK & TPACK \\
\hline TK & & & & & & & \\
\hline PK & $.312^{* *}$ & & & & & & \\
\hline CK & $.551^{* *}$ & $.613^{* *}$ & & & & & \\
\hline TPK & $.506^{* *}$ & $.523^{* *}$ & $.498^{* *}$ & & & & \\
\hline PCK & $.320^{* *}$ & $.783^{* *}$ & $.489^{* *}$ & $.545^{* *}$ & & & \\
\hline TCK & $.668^{* *}$ & $.263^{* *}$ & $.397^{* *}$ & $.435^{* *}$ & $.317^{* *}$ & & \\
\hline TPACK & $.627^{* *}$ & $.477^{* *}$ & $.628^{* *}$ & $.646^{* *}$ & $.461^{* *}$ & $.676^{* *}$ & \\
\hline
\end{tabular}

** Correlation is significant at the 0.01 level (2-tailed).

With respect to correlations between subscales, although the values of the coefficients varied from .312 (TK and PK) to .783 (PCK and PK) but all of the coefficients are positively correlated. Such results allows us to appreciate the links existing between the different TPACK model components. The components more closely related to one another are the intersections directly linked to the same section, such as TCK, TPK and TPACK as all of them related to the same section "technology".

\section{CONCLUSIONS}

When the studies regarding the scale development are examined, it is seen that a systematic and step-by-step approach is followed for the validity and reliability of the scale. In this study, a similar process is completed. The validity and reliability of the "Technological, Pedagogical, and Content Knowledge" scale TPACK survey are checked with science teachers in primary schools in Malaysia.. It consists of 47 items about TPACK on a 5-point Likert scale and is based on the survey instrument developed by Schmidt et al.,(2009). Then, EFA is conducted to examine the construct validity and the factor structure of the survey. Based on the EFA, the results show the survey items for each subscale successfully measure each variable. KMO and BTS measures also indicate the data satisfy the psychometric criteria for the EFA.

Furthermore, item-total correlations and Cronbach's alpha internal consistency coefficient are calculated. For scales used in research, the level of an acceptable Cronbach's alpha coefficient is suggested as 0.70 . In the present study, findings suggest that Cronbach's alpha coefficients of the subscales show the internal consistency of the scale.

In addition, Pearson's linear correlation $r$ coefficient was analysed in order to study the relationship existing between the different TPACK model components. All of the coefficients are positively correlated. Such results allows us to appreciate the links existing between the different TPACK model components. The correlation scores show that significant interactions between technology, pedagogy, and content knowledge bases are evident.

Findings from the current study supports the intertwined relationship between the three knowledge bases. In fact, if science teachers see the value of integration 
of appropriate educational technologies and pedagogies into their content area, they will more likely use these technologies and pedagogies to support student learning when they become real teachers. It is apparent that much research in this line of inquiry should be conducted. Also, future research could conduct the TPACK survey with different research designs and contexts (Sahin, 2011)2.

\section{REFERENCES}

Chan, By, \& F.-M. (2002). ICT in Malaysian Schools: Policy and Strategies. Retrieved June 2, 2014, from http://gauge.u-gakugei.ac.jp/.

DeCoster, J. (1998). Overview of Factor Analysis. Retrieved August 20, 2016, from http://www.stat-help.com/notes.html.

Fu, J. S. (2013). ICT in Education: A Critical Literature Review and Its Implications. International Journal of Education and Development Using Information and Communication Technology (IJEDICT), 9(1), 112-125.

Graham, C. R. (2011). Theoretical considerations for understanding technological pedagogical content knowledge (TPACK). Computers and Education, 57(3), 1953-1960. doi:10.1016/j.compedu.2011.04.010.

Harris, J. B., \& Hofer, M. J. (2011). Technological pedagogical content knowledge in action: A descriptive study of secondary teachers' curriculum-based, technologyrelated instructional planning. Journal of Research on Technology in Education, 43(4), 211.

Hasniza Nordin. (2014). Pre-Service Teachers' TPACK and Experience of ICT Integration in Schools in Malaysia and New Zealand. University of Canterbury, New Zealand.

Junnaina, H. C., \& Hazri, J. (2014). The Effect of Field Specialization Variation on Technological Pedagogical Content Knowledge (TPACK) Among Malaysian TVET Instructors. The Malaysian Online Journal of Educational Technology, 2(1), 36-44.

Karadeniz, Ş., \& Vatanartiran, S. (2013). Adaptation of a TPACK survey to Turkish for secondary school teachers. International Journal of Human Sciences, 10(2), 34 - 47. Retrieved from http://www.j-humansciences.com/ojs/index.php/IJHS/ article/view/2636

Khaddage, Ferial, \& Knezek, G. (2013). Introducing a Mobile Learning Attitude Scale for Higher Education. In X World Conference on Computers in Education,. Toruń, Poland.

Koç, M. (2005). Implications of Learning Theories for Effective Technology Integration and Pre-service Teacher Training: A Critical Literature Review. Journal of Turkish Science Education, 2(1), 2-18.

Kothari, C. R. (2004). Research Methodology: Methods and Techniques. New Age International Publishers.

Kubiatko, M. , \& Haláková, Z. (2009). Slovak High School Students’ Attitudes to ICT Using in Biology Lesson. Computers in Human Behavior, 25, 743-748.

Look, D. (2005). Discussion Paper: Impact of Technology on Education. 
Mishra, P., \& Koehler, M. J. (2006). Technological pedagogical content knowledge: A framework for teacher knowledge. Teachers College Record, 108(6), 10171054. doi:10.1111/j.1467-9620.2006.00684.x

Mohd Zaki M., Faizal M.A., Erman H., Nazrulazhar B., A., Nor Azman M., \& Y., A. N. (2009). ICT Development In Malaysia. In Paper presented at the Seminar on Information Technology 2009 (SemiT 2009). SemiT 2009.

Sahin, I. (2011). Development of Survey of Technological Pedagogical and Content Knowledge (TPACK). Turkish Online Journal of Educational Technology TOJET, 10(1), 97-105.

Schmidt, D. a., Baran, E., Thompson, A. D., Koehler, M. J., Shin, T. S., \& Mishra, P. (2009). Technological Pedagogical Content Knowledge ( TPACK ): The Development and Validation of an Assessment Instrument for Preservice Teachers. Journal of Research on Technology in Education, 42(2), 123-149. doi:10.1007/978-1-60761-303-9.

Tam, M. (2000). Constructivism, Instructional Design, and Technology: Implications for Transforming Distance Learning. Educational Technology \& Society, 3(2).

Taylor, L. , \& Parsons, J. (2011). Improving Student Engagement. Current Issues in Education, 14(1), 1-32.

Yong, A. G., \& Pearce, S. (2013). A Beginner' s Guide to Factor Analysis : Focusing on Exploratory Factor Analysis, 9(2), 79-94. 